\title{
Gendered access to land and household food insecurity: Evidence from Nigeria
}

\author{
Amaka Nnaji ${ }^{1,2}$ (D), Nazmun N. Ratna ${ }^{1 \star}$ and Alan Renwick ${ }^{1}$ \\ ${ }^{1}$ Department of Global Value Chain and Trade, Faculty of Agribusiness \& Commerce, Lincoln University, \\ Lincoln, New Zealand and ${ }^{2}$ Department of Agricultural Economics, University of Nigeria, Nsukka, Nigeria \\ ${ }^{*}$ Corresponding author. Email: nazmun.ratna@lincoln.ac.nz
}

(Received 30 March 2021; revised 9 July 2021; accepted 11 July 2021; first published online 12 August 2021)

\begin{abstract}
In this article, we examine the joint influence of land access and gender of household head on household food insecurity by employing a logit model and using data from the 2015/ 2016 Nigerian General Household Survey. Our results show that female-headed households (FHHs) are more food insecure than male-headed households. However, with a 1 -acre increase in their access to land, FHHs are 16 percent less likely to be food insecure. This finding provides policy insights into how improving access to arable land for landpoor FHHs can enhance food security in Nigeria.
\end{abstract}

Keywords: food security; gender; households; land access; Nigeria

JEL Code: Q12; C21; Q15; J16

\section{Introduction}

Food insecurity remains a major concern in most developing countries. Although more food is produced than the world's population needs, close to half of it ends up as food waste (FAO 2011a; Lundqvist, de Fraiture, and Molden 2008), while millions of people are left without adequate food, especially in sub-Saharan Africa (Lundqvist, de Fraiture, and Molden 2008; FAO 2017). This is even worse for female-headed households (FHHs) in developing countries, who have unequal access to productive resources (Adekola et al. 2013; Twum et al. 2020), since we know that timely access to arable land is important for reducing hunger and poverty, especially in developing countries (Pindiriri 2021; Tekwa 2020). Target 5A of the fifth Sustainable Development Goal (SDG 5) identifies the need to undertake changes to provide women with equal rights and opportunities to financial services and productive resources, like land, in accordance with the current national laws. Several studies in developing countries find that women having more access to productive resources will have a positive effect on the well-being of their household members as well as their own health and education (Handa 1996; Rogers 1996; Duflo and Udry 2004; Kennedy and Peters 1992; Doss

(c) The Author(s), 2021. Published by Cambridge University Press on behalf of the Northeastern Agricultural and Resource Economics Association. This is an Open Access article, distributed under the terms of the Creative Commons Attribution licence (http://creativecommons.org/licenses/by/4.0/), which permits unrestricted re-use, distribution, and reproduction in any medium, provided the original work is properly cited. 
1997; Adereti 2005; Pindiriri 2021). Unfortunately, in most developing countries, women experience more barriers when accessing land than men (Wineman and Liverpool-Tasie 2017; Dokken 2015; Murugani et al. 2014; Khalid, Nyborg, and Khattak 2015; Brück and Schindler 2009). Often this obstacle is not just the area of the land itself they can access, but also its quality and how productive they can make it (Gill 1988; Quisumbing et al. 1998).

With the increasing significance of the role of women in securing the nutritional status of their households (FAO 2011b; Karl 2009; Levin et al. 1999; Quisumbing et al. 1998), determining the influence of gender-specific access to land on food security is crucial. In addition, the impact of gendered access to land on the food security of households is necessary to aid in the understanding of the factors affecting agricultural production and the ways it can be improved. This study will also inform the facilitation of policies for ensuring food security and improving livelihoods for rural dwellers.

A growing number of studies have identified the differences between the food security status of male-headed households (MHHs) and FHHs (Akadiri, Nwaka, and Jenkins 2018; Tibesigwa and Visser 2016; Mallick and Rafi 2010; Joshi and Joshi 2017; Choithani 2020; Shin 2020; Ma et al. 2021). Others have examined the differences in access to land by MHHs and FHHs (Khalid, Nyborg, and Khattak 2015; Adelman and Peterman 2014; Lambrecht 2016; Wineman and Liverpool-Tasie 2017; Tran et al. 2013; Pindiriri 2021), but the literature on how and to what extent gendered access to land affects food insecurity remains scant. Understanding the nexus among gender, land access, and food security is important for implementing agricultural policies in the low-income and lower-middle-income countries.

The main objective of this study is to examine the joint effect of gender and access to land on households' food insecurity, which, to the best of our knowledge, is the first study to address the research gap on gender-land access-food insecurity literature. In this article, we use data from the 2015/2016 Nigerian General Household Survey (GHS). A logistic regression model is used to analyze the data. In Nigeria, most studies on food security are confined to certain states and districts and not the entire country (Iruonagbe 2011; Arene and Anyaeji 2010; Amaza et al. 2006). Furthermore, most of the studies in Nigeria fail to empirically determine the association between gender, access to land, and food security (Chikaire et al. 2016; Adekola et al. 2013). Given the importance of land resources as well as the significant role of women play in the well-being and nutritional status of their families, it is important to understand how, and to what extent, access to land can influence the effect of gender of household head on food insecurity.

The main finding of the study is that a 1-acre increase in land accessed by FHHs reduces their likelihood of being food insecure by 16 percent compared with MHHs. This implies that FHHs are so constrained in their access to arable land that additional access to land results in a greater impact on their food insecurity status in comparison with MHHs. Existing literature has shown that women are disproportionately disadvantaged in terms of land access. This is a consequence of structural inequalities and traditional and sociocultural gender roles that deny women the same economic opportunities as men. This is most probably the reason why increased access to land by FHHs has a disproportionate ability to improve their food security compared with MHHs. The findings of the study highlight the need for devising policies in support of Target 5A of SDG 5 , which is to facilitate reforms to ensure that women have equal rights to economic resources in addition to control over and ownership of land and other financial services.

This article makes several contributions to the literature. First, we go further than the current literature by quantifying the joint impact of land access and gender of 
household head on the food insecurity status of households. Therefore, we test whether increasing access to land for FHHs will influence their food insecurity status. Second, the study enhances an understanding of the mediating effect of land access on the influence of gender of household head on food insecurity. Finally, the findings from this study will provide significant insights into agricultural policies that focus on enhancing food availability.

The remainder of this article is organized as follows: the next section presents a summary of the relevant literature on gendered land access and food security. After this, a conceptual model linking household and household head characteristics to food insecurity and an empirical model is presented. A detailed descriptive analysis of the data is then reported. The subsequent section reports the estimated results, followed by a discussion of the results, before the concluding remarks are presented.

\section{Literature review}

\section{Food security and access to land}

Food security occurs when people have access to adequate, healthy, and nutritious food that meets their nutritional needs and preferences at all times (FAO, IFAD, UNICEF, WFP, and WHO 2017; FAO 2006; Sasson 2012). Food insecurity is of great concern in both developed and developing countries, although it is worse in the latter (Sasson 2012). In sub-Saharan Africa, insufficient food production as a result of the adverse effects of climate change is the major cause of food insecurity, although conflicts and soaring food prices are contributing factors (Day and Caus 2020; Xie et al. 2021).

Increases in access to land are found to have a positive influence on households' food security (Jayne et al. 2003; Rammohan and Pritchard 2014; Muraoka, Jin, and Jayne 2018), although income from owned land is found to be higher than that from rented land (Muraoka, Jin, and Jayne 2018; Abdulai, Owusu, and Goetz 2011; Ali, Abdulai, and Goetz 2012; Abdulai and Goetz 2014). Tenure security influences households' rights to use, manage, and control land and its resources (Holden and Ghebru 2016). This has a clear and positive impact on land rights, agricultural productivity, and, hence, household food security (Deininger and Jin 2006; Ghebru and Holden 2013; Holden and Ghebru 2016). If total food production is a key factor affecting the food security of developing countries (Sasson 2012), then security of tenure and the resulting area of land accessed is key in determining the influence of land access on the food security of households in these countries. Disparities in access to productive resources like land can be the difference between a food-secure and a food-insecure household (Tekwa 2020), while variation in the ability of the different genders to access land will have a further influence on their food security.

\section{Gender and food security}

Many studies have sought to determine the influence of the gender of household head on the household's food security status. MHHs are found to be more food secure than FHHs in Nigeria, Ethiopia, Nepal, Kenya, and South Africa (Tibesigwa and Visser 2016; Joshi and Joshi 2017; Akadiri, Nwaka, and Jenkins 2018; Kassie, Ndiritu, and Stage 2014; Maharjan and Joshi 2011; Larson, Castellanos, and Jensen 2019; Shin 2020). On the other hand, in a study by Mallick and Rafi (2010) in Bangladesh, no significant difference between the food security of MHHs and FHHs is found. The authors suggest 
that the lack of evidence of a difference could be a result of a lack of sociocultural restrictions among indigenous ethnic groups, permitting women more freedom to participate in the labor market. In addition, they suggest that another reason is that FHHs are given priority during food redistribution by informal institutions, for example, "Khiang" in indigenous communities. The authors also use a subjective measure for food security, that is, the perception of respondents about their households' food security, which can be a potential limitation given the evidence of gender-based differences in perceptions about food security (Lutomia et al. 2019).

Some of the main reasons given for variations in the food security status of FHHs in comparison with their male counterparts are inadequate access to productive resources, overreliance on household food production, lower assets, and off-farm income (Tibesigwa and Visser 2016; Joshi and Joshi 2017; Iruonagbe 2011; Pindiriri 2021). Kassie, Ndiritu, and Stage (2014) also find that land quality and social capital have a positive influence on FHHs' food security. Belonging to a farmers' group and being connected with more traders in their neighborhood increases the likelihood of food security for FHHs. These farmer groups may provide financial support and access to improved inputs and extension services, which, in turn, increases the productivity of female farmers.

\section{Conceptual framework}

Figure 1 presents our conceptual framework on gender-land access-food security nexus. It highlights that social and demographic factors like age, education of household head, and social networks influence household food security (Joshi and Joshi 2017; Akadiri, Nwaka, and Jenkins 2018; Rammohan and Pritchard 2014; Brück and Schindler 2009; Kassie, Ndiritu, and Stage 2014). Material assets of the household (Joshi and Joshi 2017), farm income (Joshi and Joshi 2017; Akadiri, Nwaka, and Jenkins 2018), off-farm income (Tibesigwa and Visser 2016), location of the household (Tibesigwa and Visser 2016), as well as the infrastructure available to households, also influence food security.

The most important determinant for food availability is land access (Kassie, Ndiritu, and Stage 2014; Muraoka, Jin, and Jayne 2018), which is the focus of this article and is depicted by arrow 1 in Figure 1. We identify three ways to access land: inheritance, rent, and communal land. Among the household characteristics, we consider gender as one of the most important determinants of food security (arrow 2, Figure 1). In most lowincome and lower-middle-income countries, FHHs are usually disadvantaged in comparison with their male counterparts in terms of the access and use of productive resources like arable land (arrow 3, Figure 1) (Brück and Schindler 2009; Agarwal 2003; Lambrecht 2016; Adekola et al. 2013). This is mainly because of cultural norms that impede women from gaining equal access to land. Some communities, especially patriarchal ones, do not allow women to inherit land, and women have access to land only through their husbands and/or male relatives (Khalid, Nyborg, and Khattak 2015; Chikaire et al. 2016). Sometimes, existing norms and the culture inhibit women from having adequate access to land. For example, in some parts of Ethiopia, it is taboo for women to plow (Dokken 2015). Murugani et al. (2014) report that married women have more secure land access than single women, although most times, they do not own the land themselves (Iruonagbe 2011). In developing countries, especially in patriarchal societies, women achieve access to land through their husbands when they are married and, if unmarried, through their male relatives (father, brother, etc.). In the case of communal land, although it is in collective ownership, women are often disadvantaged 


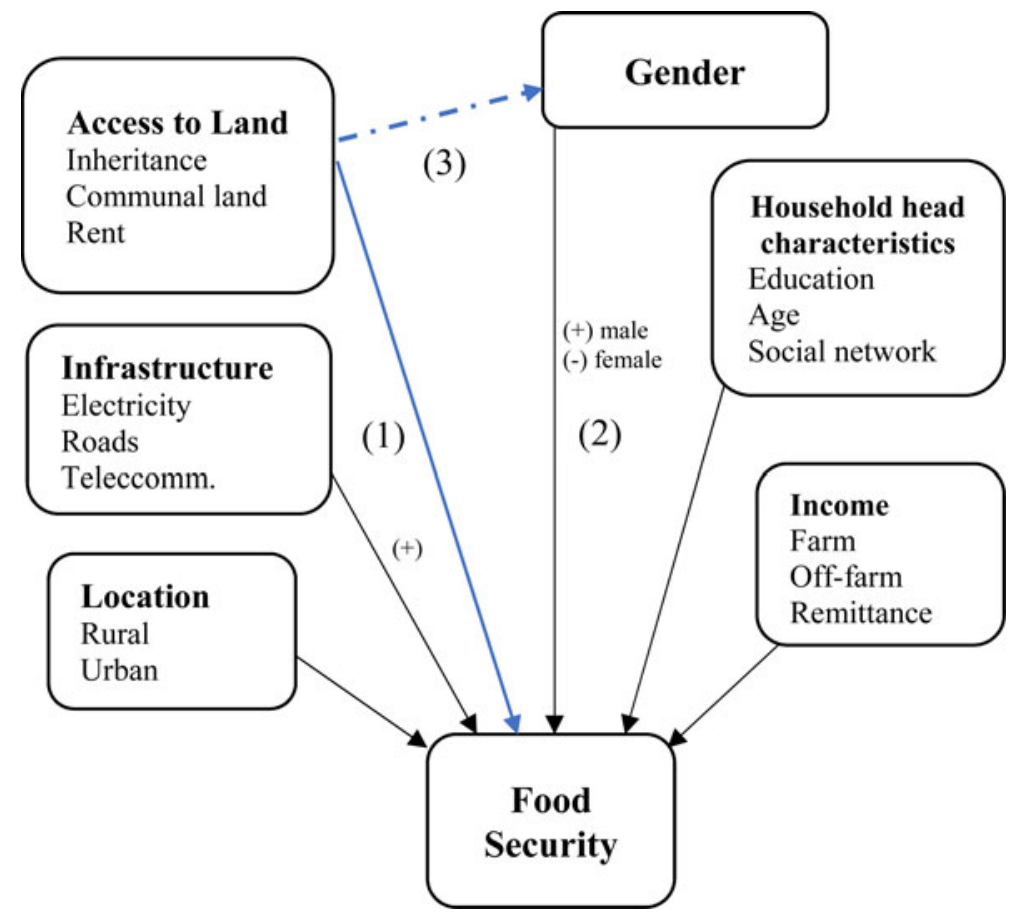

Figure 1. Conceptual Framework Linking Household and Household Head Characteristics with Food Security.

in the allocation of communal land (Iruonagbe 2011). Land accessed through a third party usually has insecure tenure and can be reclaimed at any time (Murugani et al. 2014). This can have negative implications for their finances, as land use without full rights cannot be used as collateral for availing credit facilities. In turn, this can lead to adverse consequences for their food security, as access to productive resources, like land, will have an effect on their scale of production as well as their productivity and output.

Figure 1 also reveals that three characteristics of household heads-education, age, and their social network-influence households' food security. This indicates that households with educated heads tend to be more food secure (Akadiri, Nwaka, and Jenkins 2018; Rammohan and Pritchard 2014). With a higher level of education, the household head will have more human capital, information, and the skills to use the right inputs and, therefore, increase productivity. This may also improve participation in off-farm work and, hence, they can generate more income to purchase food. Social networks are found to increase household food security (Kassie, Ndiritu, and Stage 2014).

We also include the farm size and the availability of infrastructure as determinants of household food security. Farm size and land quality are found to improve FHHs' food security status (Kassie, Ndiritu, and Stage 2014), while distance to the market has a negative effect on food security (Kassie, Ndiritu, and Stage 2014; Akadiri, Nwaka, and Jenkins 2018). Those further away from markets may be more limited in terms of both their information about the prevailing prices and their ability to sell and purchase food in the absence of an efficient transport infrastructure. Access to electricity also has 
a positive influence on household food security (Faridi and Wadood 2010). This can also be an indicator of the households' welfare and subsequent access to other resources. For example, the availability of electricity makes automated irrigation possible.

In our conceptual model, we also include household location as a determinant of food security. Tibesigwa and Visser (2016) report that the gap between the food security of both MHHs and FHHs is much wider in rural areas than in urban areas. This implies that FHHs in rural areas, with unequal access to land, are more susceptible to food insecurity as the number of off-farm opportunities for them is greatly reduced. They rely on land for sustenance to a greater extent.

\section{Empirical model}

In this study, we capture food insecurity as a dummy variable that specifies households that had to reduce meal sizes as a result of a lack of food. ${ }^{1}$ Given the dichotomous nature of the dependent variable, we specify a binary logit model to determine the impact of gendered access to land on household food insecurity. The conditional probability of being food insecure $(Y)$ is given as follows:

$$
\mathrm{p}(Y=1 \mid \mathbf{X})=1 /\left(1+e^{\alpha+\tau \text { Gender }+\eta \text { Land }+\gamma \text { Gender } * \text { Land }+\beta \mathbf{X}}\right)
$$

where $\mathrm{p}$ is the conditional probability of a household being food insecure; $Y$ is a dummy variable that indicates whether or not households have reduced meal sizes over the last 7 days because they do not have enough food and represents the likelihood of the household being food insecure; Gender is a dummy variable that indicates whether the household head is female; Land denotes the area of land that households access for cultivation; Gender ${ }^{\star}$ Land is an interaction variable that captures the mediating effect of land access on the influence of gender of household head on household food insecurity status; $\mathbf{X}$ is a vector of household, household head, and farm-level explanatory variables, while $\alpha, \tau, \eta$, and $\boldsymbol{\beta}$ are estimated coefficients. Norton, Wang, and Ai (2004) show that for nonlinear models, the full effect of the interaction variable is not equal to its coefficient $(\gamma)$, nor can its statistical significance be efficiently determined by just using a t-test. Rather, the interaction effect is the discrete difference with respect to land access of a single derivative with regard to the gender of household head. This implies that the sign, magnitude, and statistical significance of the interaction effect must be estimated from the cross-partial derivative of household food insecurity and not the coefficient of the gender-land interaction variable in equation 1 . Following Norton, Wang, and Ai (2004), we estimate the correct interaction effect of the genderland interaction variable by calculating the cross-partial derivative of the expected value of household food insecurity at different values of covariates as follows:

$$
\begin{aligned}
\frac{\Delta \frac{\delta \mathrm{p}(Y=1 \mid \mathbf{X})}{\delta \text { Gender }}}{\Delta \text { Land }}= & (\tau+\gamma)(\mathrm{p}\{(\tau+\gamma) \text { Gender }+\eta+\boldsymbol{\beta X}\} \times(1-\mathrm{p}\{(\tau+\gamma) \text { Gender } \\
& +\eta+\boldsymbol{\beta} \mathbf{X})\}-\tau[\mathrm{p}(\tau \text { Gender }+\boldsymbol{\beta} \mathbf{X})\{1-\mathrm{p}(\tau \text { Gender }+\boldsymbol{\beta} \mathbf{X})\}]
\end{aligned}
$$

\footnotetext{
${ }^{1}$ This self-assessed measure of food insecurity is used because the 2015/2016 Nigerian GHS does not have information that can be used to construct food insecurity indices like HFIAS or DDS.
} 
Equation 2 shows that the full interaction effect of the gender-land interaction variable is conditional on the independent variables. Also, the interaction effect of the gender-land interaction variable may have different signs for different values of covariates, because there are two additive terms that could be negative or positive. Consequently, the sign of the coefficient of the gender-land interaction variable in equation $1, \gamma$, does not necessarily indicate the sign of the interaction effect.

Table 1 presents the definitions and summary statistics of the variables in the model. Following the main premise of this article, a gender-land interaction term is included in the food insecurity model to capture the intervening impact of land access on FHHs' food insecurity status. All analyses are carried out using the STATA 15 statistical software.

\section{Data, variable measurements, and descriptive statistics}

\section{Data}

We use data from the third wave of the Nigerian GHS-Panel conducted in 2015/2016 (NBS 2016). Data collection included three questionnaires (agriculture, household, and community) for the postplanting and postharvest periods. The GHS-Panel sample is selected from the 2010 GHS sample and comprises about 22,200 households from 2,220 enumeration areas (EAs) and 60 primary sampling units. For the panel component, 5,000 households from 500 EAs are chosen. Some key variables like the educational level of household head are missing from the first and second waves of the GHS-Panel, so the study makes use of the third wave alone. In the third wave of the GHS-Panel, only 4,581 households completed their questionnaires. After data cleaning, transforming, and selecting for key variables, the sample for the study is reduced to 1,096 households from both urban and rural areas.

\section{Variable measurements}

In this study, we use a self-assessment measure of household food consumption as a proxy for food insecurity. This food insecurity measure is an experiential indicator that is measured using days of food shortages. Household heads are asked if they had to reduce the size of meals eaten in their households because of insufficient food. The choice of this measure is informed by our focus on the food availability pillar of food security. It is a binary variable that takes the value of 1 when households report they had to reduce the portion sizes of meals in their household over the last week (food insecure) and 0 otherwise (if food secure) ( $\mathrm{Li}$ and $\mathrm{Yu}$ 2010). Land access is captured by a household farm size, which is their total area of cultivated land measured in acres. We use the sex of the household head to examine gender differences influencing food insecurity. The gender variable takes the value of 1 for FHHs and 0 for MHHs. ${ }^{2}$ The gender-land interaction variable is included to establish the intervening effect of land access on the influence of gender of household head on household food insecurity status, which is a product of the gender and land access variables.

Control variables were included in the model to control for other household and farm-level characteristics influencing household food insecurity. The age variable

\footnotetext{
${ }^{2}$ The study does not capture possible intrahousehold impacts of gender. This may be a limitation of the study because women in MHHs and FHHs may face different challenges (Doss and Morris 2000). This suggests that obstacles women in MHHs face in accessing land and other productive resources may be different from what women in FHHs experience, and this will have consequences for their food security.
} 
Table 1. Variable Definition and Summary Statistics

\begin{tabular}{|c|c|c|c|c|c|}
\hline Variable & Definition & Mean & St. Dev. & Min. & Max. \\
\hline Food insecurity & $\begin{array}{l}1 \text { if household is food } \\
\text { insecure, } 0 \text { otherwise }\end{array}$ & 0.314 & 0.464 & 0 & 1 \\
\hline Farm size & $\begin{array}{l}\text { Size of total cultivated } \\
\text { farmland (acres) }\end{array}$ & 2.208 & 3.524 & 0 & 36.792 \\
\hline Gender & $\begin{array}{l}1 \text { if household head is } \\
\text { female, } 0 \text { otherwise }\end{array}$ & 0.066 & 0.248 & 0 & 1 \\
\hline Gender*land & $\begin{array}{l}\text { Interaction term between } \\
\text { gender and farm size }\end{array}$ & 0.032 & 0.301 & 0 & 8.084 \\
\hline Age & $\begin{array}{l}\text { Age of household head } \\
\text { (years) }\end{array}$ & 50.971 & 12.924 & 23 & 103 \\
\hline Age squared & $\begin{array}{l}\text { Squared age of } \\
\text { household head }\end{array}$ & $2,764.99$ & $1,407.19$ & 529 & 10,609 \\
\hline Household size & $\begin{array}{l}\text { Number of household } \\
\text { members }\end{array}$ & 6.932 & 3.154 & 1 & 22 \\
\hline Location & $\begin{array}{l}1 \text { if household is located } \\
\text { in a rural area, } 0 \\
\text { otherwise }\end{array}$ & 0.848 & 0.360 & 0 & 1 \\
\hline Electricity & $\begin{array}{l}1 \text { if households are } \\
\text { connected to national } \\
\text { electricity grid, } 0 \\
\text { otherwise. }\end{array}$ & 0.467 & 0.499 & 0 & 1 \\
\hline Education & $\begin{array}{l}1 \text { for no education, } 4 \text { for } \\
\text { tertiary education }\end{array}$ & 2.179 & 0.970 & 1 & 4 \\
\hline $\begin{array}{l}\text { Nonfarm } \\
\text { income }\end{array}$ & $\begin{array}{l}\text { Household income from } \\
\text { nonfarm sources } \\
\text { (NGA1,000) }\end{array}$ & 32.128 & 103.597 & 0 & $2,247.5$ \\
\hline Farm income & $\begin{array}{l}\text { Household income farm } \\
\text { sources (NGN1,000) }\end{array}$ & 192.700 & 366.166 & 0 & 5,050 \\
\hline Remittance & $\begin{array}{l}1 \text { if household received } \\
\text { remittance, } 0 \\
\text { otherwise }\end{array}$ & 0.961 & 0.192 & 0 & 1 \\
\hline $\begin{array}{l}\text { Extension } \\
\text { officer visits }\end{array}$ & $\begin{array}{l}\text { Number of extension } \\
\text { officer visits in the last } \\
\text { cropping season }\end{array}$ & 0.159 & 1.081 & 0 & 20 \\
\hline Land title & $\begin{array}{l}1 \text { if household has formal } \\
\text { land title to farmland, } \\
0 \text { otherwise }\end{array}$ & 0.06 & 0.238 & 0 & 1 \\
\hline Fertilizer use & $\begin{array}{l}1 \text { if household used } \\
\text { fertilizer, } 0 \text { otherwise }\end{array}$ & 0.634 & 0.673 & 0 & 1 \\
\hline Soil quality & $\begin{array}{l}1 \text { if soil quality of } \\
\text { farmland is good, } 0 \\
\text { otherwise }\end{array}$ & 0.835 & 0.371 & 0 & 1 \\
\hline $\begin{array}{l}\text { Distance to } \\
\text { market }\end{array}$ & $\begin{array}{l}\text { Distance from household } \\
\text { to closest market }(\mathrm{km})\end{array}$ & 68.31 & 37.57 & 0.9 & 214.3 \\
\hline
\end{tabular}

Note: NGN is the Nigerian currency; US\$1 = NGN380.50 in 2021; St. Dev. is the standard deviation. 
measures the age of household heads in years. The age squared variable is included to determine the quadratic impact of the age of household head on household food insecurity. The location variable captures whether the household is located in a rural area. The education variable measures the educational attainment of the household head, while household farm and nonfarm income is measured in terms of Naira, the Nigerian currency. The remittance variable captures households that received remittances and controls for the purpose of determining their effect on household food insecurity. The interaction with extension officers, defined by extension officer visits, is measured as the number of visits from extension officers in the preceding year. This controls for the positive influence of the adoption of improved technologies resulting from contact with extension agents (Bogale 2012; Tefera and Tefera 2014; Gebrehiwot and van der Veen 2014). The land title variable, included as an indicator for tenure security, is measured as households that have legal title and certification for their farmland. In the literature, tenure security has been found to improve household food security (Ghebru and Holden 2013; Ajefu and Abiona 2020).

The fertilizer variable, a dummy variable, captures households that use fertilizers for agricultural production. This controls for the positive effect of productive input use on production and subsequent food availability (Jena et al. 2021). It may also account for the gender-based inequity in accessing agricultural input (Ankrah, Freeman, and Afful 2020). The soil quality variable is included as an indicator for land quality and measures if the soil quality of household farmland is good. In the literature, women have been shown to be more likely to access farm plots with lower quality compared with men (Burke and Jayne 2021). Accounting for soil quality will control for the possibility of FHHs having access to only lower quality land and the effect this will have on household food insecurity. Finally, we control for household access to markets by including a variable that captures the distance from the household to the closest market (distance to market). Distance to input and output markets has been found to significantly influence household food security (Kassie, Ndiritu, and Shiferaw 2015; Aragie and Genanu 2017; Mengistu, Degaga, and Tsehay 2021).

\section{Descriptive analysis}

Table 1 presents descriptive statistics for the variables included in equation 1 . In our sample, about 31 percent of households are food insecure and cultivate an average of 2.21 acres. Less than 10 percent of households are headed by females, while the average household size is about 10. The mean age of household head is 51 years, with about 85 percent of households located in rural areas. The average annual household farm income is $\mathrm{N} 192,700$ (equivalent to $507 \mathrm{USD}$ ), while the mean annual off-farm income is $\mathrm{N} 32,061$ (equivalent to $84 \mathrm{USD}$ ). Households in our sample had an average of two extension officer visits and are located about $68 \mathrm{~km}$ from the nearest market on average, with a majority receiving remittances (96 percent). On average, about 47 percent of households are connected to the national electricity grid, 6 percent have formal land titles to their farmland, about 84 percent reported good soil quality of their farmland, while 63 percent used fertilizer for cultivation.

Table 2 presents the mean differences in key variables by gender of household head. On average, MHHs are significantly less food insecure, have higher access to land, higher farm income, more household members, and are located farther away from the market than FHHs. Female household heads are also significantly older and less educated than male household heads on average. There are no significant differences 
Table 2. Mean Difference in Key Variables by Gender of Household Head

\begin{tabular}{|c|c|c|c|c|c|}
\hline \multirow[b]{2}{*}{ Variables } & \multicolumn{2}{|c|}{ Male } & \multicolumn{2}{|c|}{ Female } & \multirow{2}{*}{$\begin{array}{c}\text { Difference } \\
\text { (t-stat) }\end{array}$} \\
\hline & Mean & St. Dev. & Mean & St. Dev. & \\
\hline Food insecurity & 0.30 & 0.46 & 0.47 & 0.50 & $-2.78^{\star \star \star}$ \\
\hline Farm size & 2.33 & 0.11 & 0.49 & 1.08 & $10.84^{\star \star \star}$ \\
\hline Age & 50.58 & 12.97 & 56.56 & 10.91 & $-4.43^{\star \star \star}$ \\
\hline Household size & 7.09 & 3.12 & 4.63 & 2.65 & $7.54^{\star \star \star}$ \\
\hline Location & 0.85 & 0.36 & 0.81 & 0.40 & 0.93 \\
\hline Education & 2.19 & 0.98 & 1.97 & 0.84 & $2.14^{\star \star}$ \\
\hline Nonfarm income & 32.69 & 105.32 & 22.53 & 73.57 & 1.10 \\
\hline Farm income & 202.04 & 376.20 & 59.93 & 97.48 & $8.65^{\star \star \star}$ \\
\hline Remittance & 0.96 & 0.19 & 0.94 & 0.23 & 0.66 \\
\hline Extension officer visits & 0.14 & 0.91 & 0.38 & 2.42 & -0.81 \\
\hline Land title & 0.06 & 0.24 & 0.06 & 0.23 & 0.18 \\
\hline Fertilizer use & 0.65 & 0.67 & 0.39 & 0.64 & $3.35^{\star \star \star}$ \\
\hline Soil quality & 0.83 & 0.37 & 0.83 & 0.38 & 0.04 \\
\hline Distance to market & 69.45 & 37.76 & 52.08 & 30.62 & $4.57^{\star \star \star}$ \\
\hline
\end{tabular}

Note: ${ }^{\star \star}$, and ${ }^{\star \star \star}$ represent significance at 5 and 1 percent levels, respectively.

Source: Authors' calculation from the 2015/2016 Nigerian GHS data.

in terms of the location of household, nonfarm income, remittance receipt, extension officer visit, land title, and soil quality.

Table 3 indicates that about 93 percent of the sample are MHHs, with about threequarters of them being food secure. In comparison, about 57 percent of the FHHs are food secure with a greater share of these households residing in rural areas (Table 4). Table 3 reports that about 24 percent of MHHs and 43 percent of FHHs in our sample are food insecure. The gender variable has a statistically significant positive correlation with the food insecurity variable $(0.090)$ at the 1 percent level of significance (Table A1). This implies that FHHs are more likely to be food insecure in comparison with MHHs.

Female household heads are older than their counterparts on average and also have much less access to land. ${ }^{3}$ One reason for the difference in age may be that a majority of the female heads are either divorced or widowed in comparison with the male heads; hence, they are more likely to be older. ${ }^{4}$ Similarly, Milazzo and Van de Walle (2015) and Ruwanpura and Humphries (2003) also find female heads to be older, with the main causes of female headship being widowhood and divorce. The household size of FHHs is almost 50 percent lower, on average, than that of MHHs. Oginni,

\footnotetext{
${ }^{3}$ Tibesigwa and Visser (2016) also found female household heads to be older on average.

${ }^{4}$ In our sample, about 87 and 67 percent of widowed and divorced household heads, respectively, are females.
} 
Table 3. Mean Distribution of Households by Demographic Characteristics and Food Insecurity Status

\begin{tabular}{llllllll}
\hline & & \multicolumn{3}{l}{ Food insecurity } & & \multicolumn{2}{l}{ Total } \\
\cline { 3 - 7 } Gender & Age & No & & Yes & & & \\
\cline { 3 - 7 } Male & 50.57 & 781 & $76.27 \%$ & 243 & $23.73 \%$ & 1,024 & $93.43 \%$ \\
\hline Female & 56.55 & 41 & $56.94 \%$ & 31 & $43.06 \%$ & 72 & $6.57 \%$ \\
\hline Total & & 822 & $100 \%$ & 274 & $100 \%$ & 1,096 & $100 \%$ \\
\hline
\end{tabular}

Source: Authors' calculation from the 2015/2016 Nigerian GHS data.

Table 4. Mean Distribution of Characteristics of MHHs and FHHs

\begin{tabular}{lllcccc}
\hline Gender & $\begin{array}{l}\text { Rural } \\
(N)\end{array}$ & $\begin{array}{l}\text { Urban } \\
(N)\end{array}$ & $\begin{array}{c}\text { Land } \\
\text { size } \\
\text { (acres) }\end{array}$ & $\begin{array}{c}\text { Nonfarm } \\
\text { income }\end{array}$ & $\begin{array}{c}\text { Farm } \\
\text { income }\end{array}$ & $\begin{array}{c}\text { Household } \\
\text { size }\end{array}$ \\
\hline Male & 871 & 153 & 2.33 & 32.69 & 202.04 & 7.09 \\
\hline Female & 58 & 14 & 0.49 & 22.53 & 59.93 & 4.62 \\
\hline
\end{tabular}

Source: Authors' calculation from the 2015/2016 Nigerian GHS data.

Ahonsi, and Ukwuije (2013) and Milazzo and Van de Walle (2015) also find that MHHs are larger than FHHs. ${ }^{5}$

Table 4 shows that, on average, MHHs have about 3.4 and 1.4 times more farm and nonfarm income than FHHs, respectively. ${ }^{6}$ One reason for the large difference in farm income between both types of households is that FHHs generally have less access to agricultural land. Even in cases where they do have similar access, they may not have enough family labor, access to markets, and inputs to cultivate their land productively. Table 5 illustrates that most household heads had a primary education, with relatively few MHHs or FHHs having a tertiary education.

Table 6 shows descriptive statistics by geopolitical regions in Nigeria. Households in the North East and the North Central zones were found to have the largest access to land compared with households in the South East and South geopolitical zones. Figure 2 illustrates that the northern region makes up about two-thirds of the landmass of Nigeria, even though most of the population is situated in the southern region. Consequently, households in the northern regions have more access to land than those in the south, as illustrated in Table 6. Households in the northern geopolitical zones, on average, also have more household members than those in the south. In agrarian regions, this could signify more family labor, which will reduce costs and increase productivity. But, on the other hand, this could also imply more mouths to feed and a subsequent lack of food. The average age of household heads is lower in the northern regions than in the southern regions (Table 6). On average, households in the South East zone have the highest age for household heads, smallest land sizes, and the second to smallest household sizes.

\footnotetext{
${ }^{5}$ Milazzo and Van de Walle (2015) also report that FHHs have a higher dependency ratio than MHHs, contrary to the findings of Oginni, Ahonsi, and Ukwuije (2013).

${ }^{6}$ Agrees with the findings of Kennedy and Peters (1992) and Akadiri, Nwaka, and Jenkins (2018).
} 
Table 5. Distribution of Households by Educational Attainment and Gender

\begin{tabular}{|c|c|c|c|c|c|c|}
\hline \multirow[b]{3}{*}{ Education } & \multicolumn{6}{|c|}{ Gender } \\
\hline & \multicolumn{3}{|c|}{ Male } & \multicolumn{3}{|c|}{ Female } \\
\hline & $n$ & $\%$ & $\begin{array}{c}\text { Total HH } \\
(\%)\end{array}$ & $N$ & $\%$ & $\begin{array}{c}\text { Total HH } \\
(\%)\end{array}$ \\
\hline No education & 287 & 28.03 & 26.19 & 22 & 30.56 & 2.01 \\
\hline Primary education & 374 & 36.52 & 34.12 & 34 & 47.22 & 3.10 \\
\hline Secondary education & 241 & 23.54 & 21.99 & 12 & 16.67 & 1.09 \\
\hline Tertiary education & 122 & 11.91 & 11.13 & 4 & 5.56 & 0.36 \\
\hline Total & 1,024 & 100 & 93.43 & 72 & 100 & 6.57 \\
\hline
\end{tabular}

Note: $\mathrm{HH}$ denotes the household.

Source: Authors' calculation from the 2015/2016 Nigerian GHS data.

Table 6. Demographic Characteristics of Households by the Geopolitical Zone

\begin{tabular}{llccc}
\hline & & \multicolumn{3}{c}{ Mean } \\
\cline { 3 - 4 } Zone & $n$ & Age (years) & Land size (acres) & Household size \\
\hline North Central & 140 & 47.87 & 3.63 & 7.58 \\
\hline North East & 181 & 47.32 & 4.66 & 8.69 \\
\hline North West & 272 & 47.69 & 2.14 & 8.31 \\
\hline South East & 206 & 57.54 & 0.32 & 5.18 \\
\hline South South & 186 & 51.98 & 0.55 & 5.82 \\
\hline South West & 111 & 54.95 & 2.80 & 4.95 \\
\hline
\end{tabular}

Source: Authors' calculation from the 2015/2016 Nigerian GHS data.

\section{Results and discussion}

\section{Gendered access to land and food security}

We estimate equation 1 using a maximum likelihood estimator and present the results in Table 7. The estimated coefficients in Column 2 of Table 7 indicate that the gender of household head, area of land accessed, and educational level of household head are statistically significant at the 5percent level. The total farm income, fertilizer use, and soil quality are significant at the 1percent level, while the gender-land interaction variable is significant at the 10percent level. Of the significant variables, the area of land accessed, gender-land interaction, educational level, fertilizer use, and soil quality negatively influence food insecurity, while the gender of the household head has a positive influence.

The estimated marginal effect for the gender variable (Column 3, Table 7) shows that FHHs are about 14 percent more likely to be food insecure than MHHs. This finding is similar to that of the vast majority of studies in the literature (Tibesigwa and Visser 2016; Joshi and Joshi 2017; Akadiri, Nwaka, and Jenkins 2018; Kassie, Ndiritu, and 


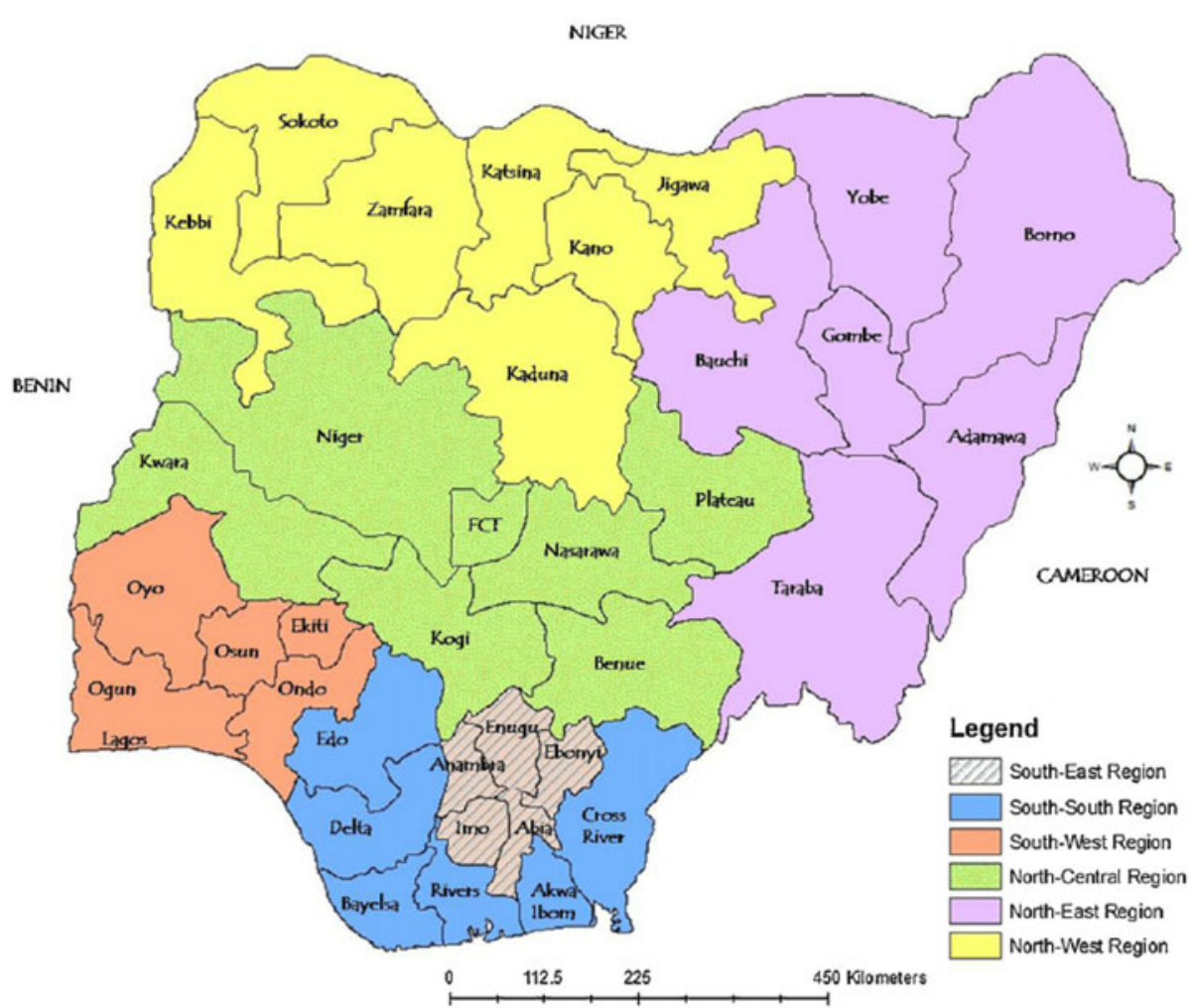

Figure 2. Map of Nigeria Showing the Geopolitical Zones. Source: Ekong et al. (2012). 
Table 7. Estimation Result of the Food Insecurity Model

\begin{tabular}{|c|c|c|}
\hline \multirow[b]{2}{*}{ Explanatory variables } & \multicolumn{2}{|c|}{ Food insecurity model } \\
\hline & Odds ratio & Marginal effect \\
\hline Farm size & $0.938(0.028)^{\star \star}$ & $-0.012(0.006)^{\star \star}$ \\
\hline Gender & $2.008(0.659)^{\star \star}$ & $0.138(0.064)^{\star \star}$ \\
\hline Gender*land & $0.299(0.197)^{\star}$ & $-0.239(0.129)^{\star}$ \\
\hline Age & $1.001(0.006)$ & $0.000(0.001)$ \\
\hline Age squared & $1.000(0.000)$ & $0.000(0.000)$ \\
\hline Household size & $0.975(0.024)$ & $-0.005(0.005)$ \\
\hline Location & $1.076(0.209)$ & $0.014(0.038)$ \\
\hline Electricity & $1.054(0.161)$ & $0.010(0.030)$ \\
\hline Education & $0.833(0.066)^{\star \star}$ & $-0.036(0.016)^{\star \star}$ \\
\hline Nonfarm income & $1.000(0.000)$ & $-0.000(0.000)$ \\
\hline Farm income & $1.000(0.000)^{\star \star \star}$ & $-0.000(0.000)^{\star \star \star}$ \\
\hline Remittance & $1.900(0.779)$ & $0.127(0.081)$ \\
\hline Extension officer visits & $0.960(0.078)$ & $-0.008(0.016)$ \\
\hline Land title & $0.948(0.289)$ & $-0.011(0.060)$ \\
\hline Fertilizer use & $0.682(0.076)^{\star \star \star}$ & $-0.076(0.022)^{\star \star \star}$ \\
\hline Soil quality & $0.611(0.108)^{\star \star \star}$ & $-0.097(0.034)^{\star \star \star}$ \\
\hline Distance to market & $0.997(0.002)$ & $-0.001(0.000)$ \\
\hline Constant & $1.167(0.636)$ & \\
\hline Sample & 1,096 & 1,096 \\
\hline$p>\chi^{2}$ & 0.000 & 0.000 \\
\hline $\mathrm{R}^{2}$ & 0.0701 & 0.0701 \\
\hline
\end{tabular}

Notes: ${ }^{*}{ }^{* \star}$, and ${ }^{* \star *}$ represent significance at 10,5 , and 1 percent levels, respectively; the SE values are in parenthesis. Dependent variable equals 1 if a household is classified as food insecure, and 0 otherwise

Stage 2014), although, as noted earlier, Mallick and Rafi (2010) found no significant difference in the food security status of MHHs and FHHs in Bangladesh using a generalized threshold model. One reason given for this contradictory result is the lack of traditional and social limitations among indigenous groups in the Chittagong Hill Tracts in Bangladesh. This affords women the freedom to partake in the labor market and other income-generating activities. In contrast, our findings are explained by the fact that in the case of Nigeria and most other developing countries, women are still discriminated against in their access to the most productive resources.

The estimated marginal effect for farm size, which is the variable representing land access (Column 3, Table 7), indicates that a 1-acre increase in the total land area accessed by households reduces the likelihood of food insecurity by 1.2 percent. This result is in line with those in other studies from Kenya, Ethiopia, and Myanmar (Muraoka, Jin, and Jayne 2018; Ghebru and Holden 2013; Rammohan and Pritchard 
2014) but disagrees with that of a study in South Africa that finds land grant recipients are more food insecure than nonrecipients in land redistribution projects (Valente 2009). ${ }^{7}$ In this case, it may be that the majority of households that are land reform beneficiaries are disadvantaged to start with and are further burdened by relocation and travel costs of participating. In general, with more access to land and the corresponding yields and income, rural households are better equipped to combat food insecurity either by consuming their own produce or by selling their outputs and purchasing food with the proceeds.

The estimated marginal effect of the education variable in Column 3 of Table 7 indicates that households with the household head having a tertiary education are less likely to be food insecure, as higher education reduces the probability of household food insecurity by about 3.6 percent in comparison. Pinckney and Kimuyu (1994), Rammohan and Pritchard (2014), Tibesigwa and Visser (2016), and Akadiri, Nwaka, and Jenkins (2018) also find a positive relationship between the educational level of the household head and household food security. This suggests that with a higher level of education, the household head may have access to more human capital, information, and skills needed to use the right inputs, therefore increasing their productivity. This may also increase participation in off-farm work and, therefore, result in more income to purchase food.

In agreement with Gebrehiwot and van der Veen (2014), the estimated coefficient for farm income is negative and statistically significant. Considering that most households in the survey are located in rural areas, this suggests that households with a higher farm income have more access to food and are, therefore, less food insecure. The estimated marginal effect of the fertilizer use variable in Column 3 of Table 7 indicates that using fertilizer for cultivation reduced the likelihood of a household being food insecure by 7.5 percent. Fertilizer use has been found to improve agricultural productivity, which, in turn, increases household income and subsequently their capacity to access a variety of food through the market (Jena et al. 2021). The estimated marginal effect of the soil quality variable in Column 3 of Table 7 shows that households cultivating on farmland with good soil quality are 9.8 percent less likely to be food insecure. This implies that households cultivating land with good soils may have better yields resulting in increased food availability and income.

Most importantly, the estimated marginal effect of the interaction term between FHHs and land (Column 3, Table 7) is negative and statistically significant at the 10 percent level. Following Allison $(2014)$, a Wald test $\left(\chi^{2}=3.37\right.$ and $\left.\mathrm{p}<0.10\right)$ and a likelihood ratio test $\left(\chi^{2}=5.31\right.$ and $\left.\mathrm{p}<0.05\right)$ are carried out to compare models with and without the interaction variable. ${ }^{8}$ We reject the null hypothesis that the coefficient of the interaction variable is statistically equal to zero at the 0.10 and 0.05 significance levels, respectively. This shows that the coefficient of the interaction variable is statistically different from zero and improves the fit of the model.

We probe the significance of the gender-land interaction variable by computing the average marginal effects of the gender of household head on household food insecurity at three different levels of land access: one standard deviation (St. Dev.) below the mean,

\footnotetext{
${ }^{7}$ Land grant recipients had extra access to land compared with nonrecipients.

${ }^{8}$ To probe the discrepancy in statistical significance of the interaction term in the Wald and likelihood ratio tests, Supplementary Table A1 compares the results of the food insecurity models with and without the gender-land interaction variable. The model with the interaction term has a higher log-likelihood and, hence, is preferred.
} 
Table 8. Average Marginal Effect of Gender on Food Insecurity at Different Levels of Land Access

\begin{tabular}{lcccccc}
\hline Land access & $\mathrm{d} y / \mathrm{d} x$ & $\mathrm{SE}$ & $\mathrm{Z}$ & $\mathrm{p}>|\mathrm{z}|$ & \multicolumn{2}{c}{$95 \% \mathrm{Cl}$} \\
\hline 1 St. Dev. $<\bar{x}$ & -0.257 & 0.139 & -1.85 & 0.065 & -0.530 & 0.016 \\
\hline $\bar{x}$ & -0.241 & 0.131 & -1.85 & 0.065 & -0.497 & 0.015 \\
\hline 1 St. Dev. $>\bar{x}$ & -0.221 & 0.121 & -1.83 & 0.067 & -0.458 & 0.015 \\
\hline
\end{tabular}

Note: SE is the standard error; $\bar{x}$ is the mean.

Table 9. Mean Interaction Effect of the Gender-Land Interaction Variable

\begin{tabular}{lcccc}
\hline Variable & Mean & Std. Dev. & Min. & Max. \\
\hline Interaction effect & -0.1615 & 0.1268 & -0.3039 & 0.0148 \\
\hline
\end{tabular}

Note: Std. Dev. is the standard deviation.

at the mean, and one St. Dev. above the mean area of land (Table 8). The estimated coefficients in Column 2 of Table 8 indicate that FHHs are more likely to report food security with additional access to land, not only at the mean land access but also at both one St. Dev. below and one St. Dev. above the mean land access. Although the probability is higher for female households with lower levels of land access in comparison with those with a higher access to land, these results show that the likelihood of FHHs being food secure increases depending on the area of land they have access to. FHHs with a small area of land access have a slightly higher probability of being food secure with an increased access to land. This reveals that the efficiency by which increased access to land improves the food security of households depends on the area of cultivated land they have access to. Improving access to land has more impact in terms of increasing the likelihood of being food secure for those FHHs that had less access originally. This finding is in line with that of Pindiriri (2021), who finds that the transfer of arable land to FHHs will lead to reduced poverty and hunger only if it targets those households with fewer than 3 acres of land or no land at all.

\section{Estimating the nonlinear interaction effect}

As noted earlier, the coefficient of the gender-land interaction variable in equation 1 (Table 7) does not take into consideration the nonadditive effect of the interaction term over the individual effects of both the gender and land variables. To overcome this problem, we estimate the full interaction effect by analyzing equation 2. Table 9 reports the full interaction effect and standard errors of the gender-land interaction variable by estimating the cross-partial derivatives of the expected value of food (in) security at different values of covariates. The results show that the mean interaction effect is -0.1615 and varies between -0.304 and 0.015 . This implies that for some FHHs, the interaction variable is negative, while for others, it is positive. The mean interaction effect reveals that with an extra 1 acre of arable land, the likelihood of FHHs self-reporting food insecurity decreases by about 16 percent compared with MHHs, ceteris paribus. This confirms the hypothesized causal pathway, denoted by arrow 3 in Figure 1, and implies that improving timely access to productive resources like land will help in preventing the vulnerability of FHHs to food shortages. 


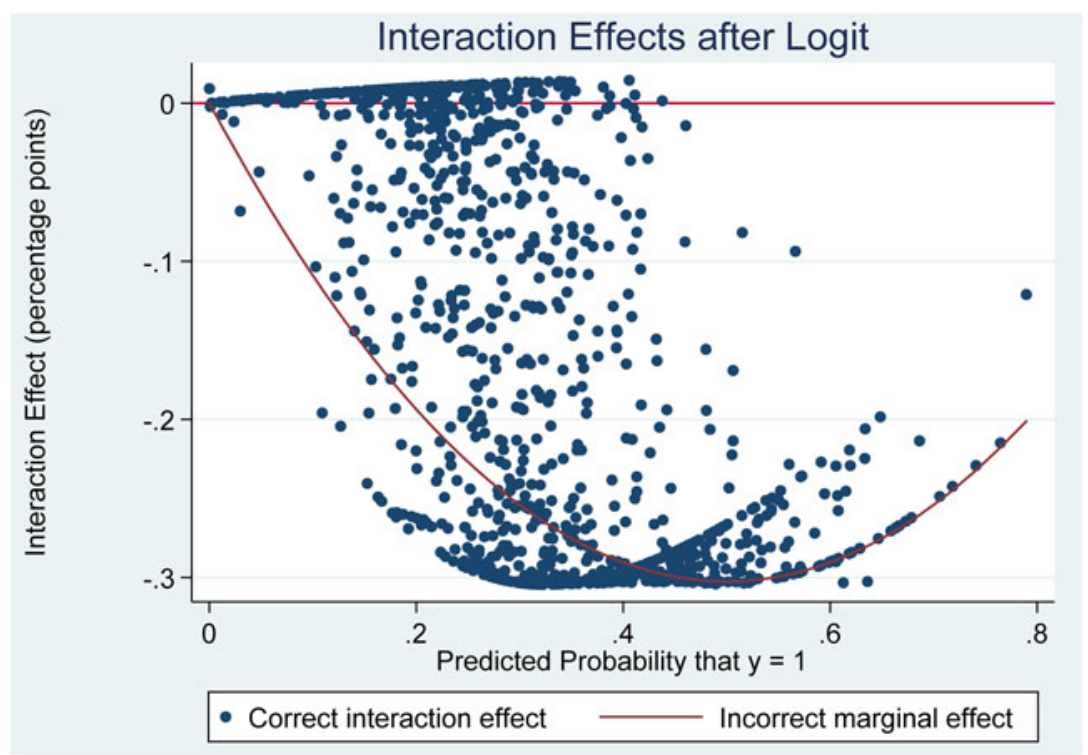

Figure 3. Plot of Interaction Effects and Predicted Probability of Reporting Food Insecurity. Source: Authors' computation.

This finding may be a result of female household heads being better household resource managers than their male counterparts (Levin et al. 1999), even when they are disadvantaged in terms of their access to productive resources (Adesina and Djato 1997). Also, many studies find that resource decisions made by female household heads improve the welfare of their households more than that when made by male household heads (Agarwal 2003; Felker-Kantor and Wood 2012; Rao 2006; Levin et al. 1999). Although the results do show that the interaction effect could be positive for different values of the covariates, this suggests that for some FHHs, extra access to land has no effect on their food security. This is possible when households with ample access to land do not have adequate inputs or sufficient labor to make the land productive.

To investigate the significance of our results further, we plot graphs of the genderland interaction effect against the predicted probability of households being food insecure and the z-statistics of the interaction effect against the predicted probability of being food insecure (Figures 3 and 4). This shows how the significance and magnitude of the gender-land interaction effect varies.

For households with a predicted probability of reporting food insecurity between 0 and 0.3 (toward the left side of Figure 3), the gender-land interaction effect is positive for some households but negative for the majority. On the right side of Figure 3, we can see that for households with predicted probabilities of above 0.5 , their interaction effects are mainly negative. This suggests that the more food insecure an FHH is, the higher the positive effect of extra land access will be on their food security.

Figure 4 indicates that in terms of significance, most of the households with a predicted probability of reporting food insecurity below 0.5 have statistically significant interaction effects. On the other hand, for households with predicted probabilities 


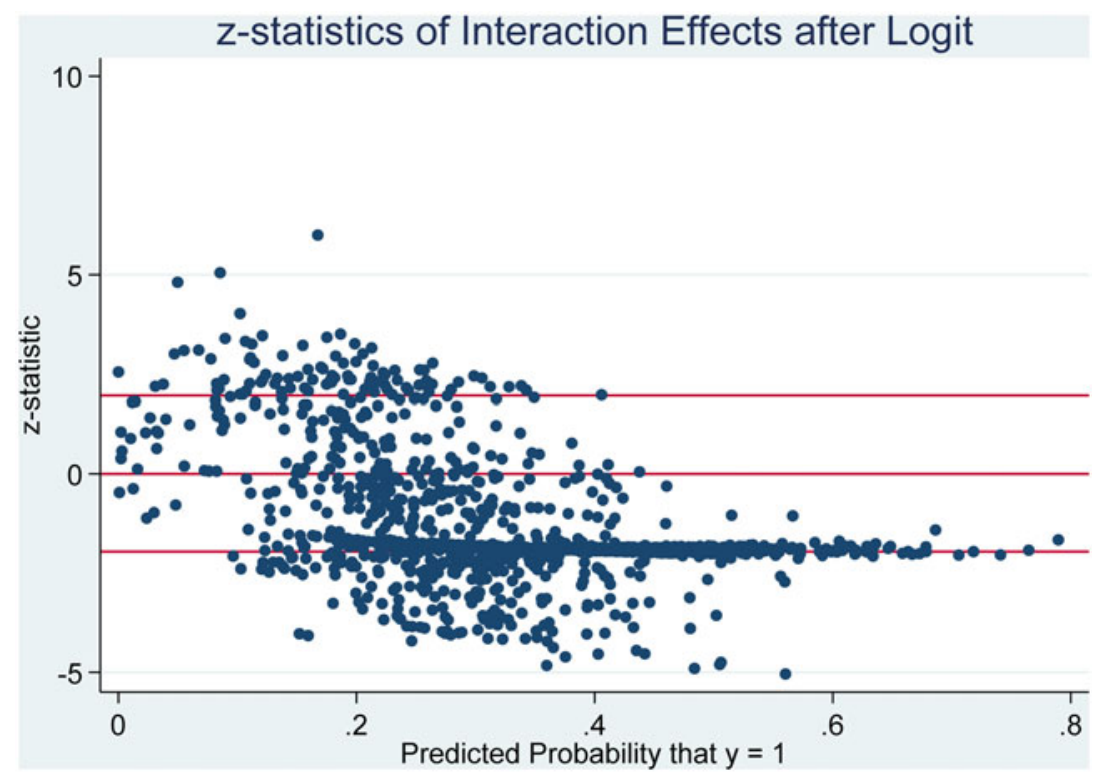

Figure 4. Plot of z-Statistics of Interaction Effects and Predicted Probability of Reporting Food Insecurity. Source: Authors' computation.

above 0.5 , their interaction effects are mostly insignificant (Figure 4). Consequently, even with a significant coefficient for the interaction variable in the logit regression output, the estimation of the interaction effect based on cross-partial derivatives of food insecurity shows that not all gender-land interaction effects are significant. This highlights the importance of capturing the nonlinear interaction effect of the gender-land interaction term, which to the best of our knowledge, has not been done in previous studies.

\section{Conclusions}

Using Nigerian data from 1,096 households, this article has extended the current literature by quantifying the joint effect of the gender of household head and access to land on food insecurity using a binary logit model. The findings show that FHHs are more food insecure than MHHs. Also, an increase in land access diminishes the probability of households being food insecure. An analysis of the interaction effect of the gender-land interaction term shows that with a 1-acre increase in land access, the likelihood of FHHs being food insecure decreases by about 16 per cent, in comparison with MHHs. However, our results also show that for some FHHs, extra access to land has no effect on their food security status. This could be because they do not have the means and resources to cultivate the land and make it productive.

The study does have some limitations. First, it does not capture possible intrahousehold gender differences. This is a limitation, because women in both MHHs and FHHs may face different challenges in terms of access to productive resources. Second, the sample is not inherently a representation of the Nigerian population. Also, the lack 
of observations in some regions means that zonal differences are not accounted for adequately, and this may result in zonal misrepresentation.

Notwithstanding these limitations, the results of this study not only add to the literature but also have implications for policy and food security interventions. First, it emphasizes the need for gender equity in accessing land in order to ensure food security. Discrepancies in educational attainment and income between men and women may further increase the food security disparity between $\mathrm{MHH}$ and FHHs. Second, the findings can help inform policy implementation around issues of land access and land tenure systems, not only in Nigeria but also in other developing countries in support of SDG 5 for gender equality and empowerment of marginalized women. These initiatives have to take into consideration the deep-rooted traditional and cultural beliefs in Nigeria that increase the discrimination against women. For example, land redistributive reforms that tackle discrimination against women in terms of land ownership and timely access to land for economic advancement will invariably improve food security for their households.

Acknowledgements. This material is based upon a doctoral thesis funded by the New Zealand Ministry of Foreign Affairs and Trade (MFAT). The authors gratefully acknowledge insightful comments from two blind reviewers.

Conflict(s) of interest. The authors declare none.

Data availability statement. The data that support the findings of this study are openly available in the World Bank Microdata library at http://microdata.worldbank.org with Reference ID No. NGA-NBSNGHPH-2016-v1.0.

\section{References}

Abdulai, A., and R. Goetz. 2014. "Time-Related Characteristics of Tenancy Contracts and Investment in Soil Conservation Practices." Environmental and Resource Economics 59(1): 87-109.

Abdulai, A., V. Owusu, and R. Goetz. 2011. "Land Tenure Differences and Investment in Land Improvement Measures: Theoretical and Empirical Analyses.” Journal of Development Economics 96 (1): 66-78.

Adekola, A.G., F.O. Adereti, G.F. Koledoye, and P.T. Owombo. 2013. "Gender Discrimination in Agricultural Land Access: Implications for Food Security in Ondo State, Nigeria." Journal of Development and Agricultural Economics 5(2): 49-56.

Adelman, S., and A. Peterman. 2014. "Resettlement and Gender Dimensions of Land Rights in Post-Conflict Northern Uganda.” World Development 64: 583-596.

Adereti, F.O. 2005. "Rural Women's Access to and Control over Productive Resources: Implications for Poverty Alleviation Among Osun-State Rural Women, Nigeria.” Journal of Human Ecology 18(3): 225-230.

Adesina, A.A., and K.K. Djato. 1997. "Relative Efficiency of Women as Farm Managers: Profit Function Analysis in Côte d'Ivoire." Journal of the International Association of Agricultural Economists 16: 47-53.

Agarwal, B. 2003. "Gender and Land Rights Revisited: Exploring New Prospects via the State, Family and Market." Journal of Agrarian Change 3(1-2): 184-224.

Ajefu, J.B., and O. Abiona. 2020. “The Mitigating Impact of Land Tenure Security on Drought-Induced Food Insecurity: Evidence from Rural Malawi.” The Journal of Development Studies 56(12): 2169-2193.

Akadiri, S.S., I.D. Nwaka, and G.P. Jenkins. 2018. "Are Female-Headed Households Less Food Secure? Evidence from Nigeria and Ethiopia." In Allied Social Science Association Annual Conference. Philadelphia.

Ali, A., A. Abdulai, and R. Goetz. 2012. "Impacts of Tenancy Arrangements on Investment and Efficiency: Evidence from Pakistan.” Agricultural Economics 43: 85-97.

Allison, Paul D. 2014. "Measures of fit for logistic regression." Paper 1485-2014 presented at the SAS Global Forum, Washington, DC. 
Amaza, P.S., J.C. Umeh, J. Helsen, and A.O. Adejobi. 2006. "Determinants and Measurements of Food Insecurity in Nigeria: Some Empirical Policy Guide." In International Association of Agricultural Economists (IAAE) 2006 Annual Meeting. August 12-18, Queensland, Australia.

Ankrah, D.A., C.Y. Freeman, and A. Afful. 2020. "Gendered Access to Productive Resources-Evidence From Small Holder Farmers in Awutu Senya West District of Ghana." Scientific African 10: e00604.

Aragie, T., and S. Genanu. 2017. "Level and Determinants of Food Security in North Wollo Zone (Amhara Region-Ethiopia)." Journal of Food Security 5(6): 232-247.

Arene, C.J., and R.C. Anyaeji. 2010. "Determinants of Food Security Among Households in Nsukka Metropolis of Enugu State, Nigeria." Pakistan Journal of Social Sciences 30(1): 9-16.

Bogale, A. 2012. "Vulnerability of Smallholder Rural Households to Food Insecurity in Eastern Ethiopia." Food Security 4(4): 581-591.

Brück, T., and K. Schindler. 2009. "Smallholder Land Access in Post-War Northern Mozambique." World Development 37(8): 1379-1389.

Burke, W.J., and T.S. Jayne. 2021. "Disparate Access to Quality Land and Fertilizers Explain Malawi's Gender Yield Gap." Food Policy 100: 102002.

Chikaire, J.U., J.O. Orusha, A. Tim-Ashama, F.E. Nwarieji, and P.C. Amanze. 2016. "Perceived Effects of Insecure Land Rights on Rural Women's Roles in Household Food Security in Okigwe Agricultural Zone of Imo State, Nigeria." Basic Research Journal of Soil and Environmental Science 4(1): 06-14.

Choithani, C. 2020. "Gendered livelihoods: Migrating Men, Left-Behind Women and Household Food Security in India." Gender, Place \& Culture 27(10): 1373-1394.

Day, A., and J. Caus. 2020. Conflict Prevention in the Era of Climate Change: Adapting the UN to Climate-Security Risks. New York: United Nations University.

Deininger, K., and S. Jin. 2006. “Tenure Security and Land-Related Investment: Evidence from Ethiopia." European Economic Review 50(5): 1245-1277.

Dokken, T. 2015. "Allocation of Land Tenure Rights in Tigray: How Large Is the Gender Bias?" Land Economics 91(1): 106-125.

Doss, C.R. 1997. "The Effects of Women's Bargaining Power on Household Health and Education Outcomes in Ghana." In Annual Meeting of the Population Association of America (PAA). March 2729, 1997, Washington, DC.

Duflo, E., and C. Udry. 2004. Intrahousehold Resource Allocation in Cote d'Ivoire: Social Norms, Separate Accounts and Consumption Choices. Cambridge, MA: National Bureau of Economic Research.

Ekong, P.S., E. Ducheyne, T.E. Carpenter, O.A. Owolodun, A.T. Oladokun, L.H. Lombin, and D. Berkvens. 2012. "Spatio-Temporal Epidemiology of Highly Pathogenic Avian Influenza (H5N1) Outbreaks in Nigeria, 2006-2008." Preventive Veterinary Medicine 103(2-3): 170-177.

FAO. 2006. Food Security. Rome: Food and Agricultural Organisation of the United Nations.

FAO. 2011a. Global Food Losses and Food Waste: Extent, Causes and Prevention. Rome: Food and Agriculture Organisation of the United Nations.

FAO. 2011b. Women-Key to Food Security. Rome: Food and Agriculture Organization of the United Nations.

FAO. 2017. The State of Food Security and Nutrition in the World 2017: Building Resilience for Peace and Food Security. Rome: Food and Agricultural Organisation of the United Nations.

FAO, IFAD, UNICEF, WFP, and WHO. 2017. The State of Food Security and Nutrition in the World 2017: Building Resilience for Peace and Food Security. Rome: FAO. Available at: http://www.fao.org/3/a-I7695e. pdf.

Faridi, R., and S.N. Wadood. 2010. "An Econometric Assessment of Household Food Security in Bangladesh.” The Bangladesh Development Studies 33(3): 97-111.

Felker-Kantor, E., and C.H. Wood. 2012. "Female-Headed Households and Food Insecurity in Brazil." Food Security 4(4): 607-617.

Gebrehiwot, T., and A. van der Veen. 2014. "Coping with Food Insecurity on a Micro-Scale: Evidence from Ethiopian Rural Households." Ecology of Food and Nutrition 53(2): 214-240.

Ghebru, H., and S.T. Holden. 2013. Links between Tenure Security and Food Security: Evidence from Ethiopia. Norwegian University of Life Sciences (Norwegian University of Life Sciences). Available at: https://nmbu.brage.unit.no/nmbu-xmlui/bitstream/handle/11250/2478729/CLTS_WP2_2013. pdf? sequence $=1$ \&isAllowed $=y$. 
Gill, D.S. 1988. "Effectiveness of Agricultural Extension Services in Reaching Rural Women: A Synthesis of Studies from Five African Countries." In Workshop on Improving the Effectiveness of Agricultural Extension Services in Reaching Rural Women in Africa. Rome: Food and Agriculture Organisation (FAO) of the United Nations.

Handa, S. 1996. "Expenditure Behavior and Children's Welfare: An Analysis of Female Headed Households in Jamaica." Journal of Development Economics 50(1): 165-187.

Holden, S., and H. Ghebru. 2016. "Land Tenure Reforms, Tenure Security and Food Security in Poor Agrarian Economies: Causal Linkages and Research Gaps." Global Food Security 10: 21-28.

Iruonagbe, T.C. 2011. "Gender Equity and Food Security: Lessons from Ozalla Community, Edo State, Nigeria." Gender and Behaviour 9(1): 3543-3565.

Jayne, T.S., T. Yamano, M.T. Weber, D. Tschirley, R. Benfica, A. Chapoto, and B. Zulu. 2003. "Smallholder Income and Land Distribution in Africa: Implications for Poverty Reduction Strategies." Food Policy 28(3): 253-275.

Jena, P.R., H. De Groote, B.P. Nayak, and A. Hittmeyer. 2021. "Evolution of Fertiliser Use and Its Impact on Maize Productivity in Kenya: Evidence from Multiple Surveys." Food Security 13(1): 95-111.

Joshi, G.R., and B. Joshi. 2017. "Household Food Security: Trends and Determinants in Mountainous Districts of Nepal." Future of Food: Journal on Food, Agriculture and Society 5(2): 42-55.

Karl, M. 2009. "Inseparable: The Crucial Role of Women in Food Security Revisited." Women in Action $\mathbf{1}$ (1): 8-19.

Kassie, M., S. Ndiritu, and B. Shiferaw. 2015. Determinants of food security in Kenya, a gender perspective. Contributed Paper prepared for presentation at the 86th Annual Conference of the Agricultural Economics Society, University of Warwick, 16-18 April 2012.

Kassie, M., S.W. Ndiritu, and J. Stage. 2014. "What Determines Gender Inequality in Household Food Security in Kenya? Application of Exogenous Switching Treatment Regression." World Development 56: $153-171$.

Kennedy, E., and P. Peters. 1992. "Household Food Security and Child Nutrition: The Interaction of Income and Gender of Household Head." World Development 20(8): 1077-1085.

Khalid, A., I. Nyborg, and B.N. Khattak. 2015. "Whose Property Whose Authority? Gendering the Legal and Customary Practices in Ownership and Access to Land: A Case of Swat, Pakistan." Journal of Rural Studies 41: 47-58.

Lambrecht, I.B. 2016. “'As a Husband I Will Love, Lead, and Provide.' Gendered Access to Land in Ghana." World Development 88: 188-200.

Larson, J.B., P. Castellanos, and L. Jensen. 2019. "Gender, Household Food Security, and Dietary Diversity in Western Honduras." Global Food Security 20: 170-179.

Levin, C.E., M.T. Ruel, S.S. Morris, D.G. Maxwell, M. Armar-Klemesu, and C. Ahiadeke. 1999. "Working Women in an Urban Setting: Traders, Vendors and Food Security in Accra." World Development 27(11): 1977-1991.

Li, Y., and W. Yu. 2010. "Households Food Security in Poverty-Stricken Regions: Evidence from Western Rural China." Agriculture and Agricultural Science Procedia 1: 386-395.

Lundqvist, J., C. de Fraiture, and D. Molden. 2008. Saving Water: From Field to Fork: Curbing Losses and Wastage in the Food Chain. Stockholm: Stockholm International Water Institute.

Lutomia, C.K., G.A. Obare, I.M. Kariuki, and G.S. Muricho. 2019. "Determinants of Gender Differences in Household Food Security Perceptions in the Western and Eastern Regions of Kenya." Cogent Food \& Agriculture 5(1): 1694755.

Ma, C., S.K.M. Ho, S. Singh, and M.Y. Choi. 2021. "Gender Disparities in Food Security, Dietary Intake, and Nutritional Health in the United States." The American Journal of Gastroenterology 116(3): 584592.

Maharjan, K.L., and N.P. Joshi. 2011. "Determinants of Household Food Security in Nepal: A Binary Logistic Regression Analysis." Journal of Mountain Science 8(3): 403-413.

Mallick, D., and M. Rafi. 2010. "Are Female-Headed Households More Food Insecure? Evidence from Bangladesh.” World Development 38(4): 593-605.

Mengistu, D.D., D.T. Degaga, and A.S. Tsehay. 2021. "Analyzing the Contribution of Crop Diversification in Improving Household Food Security Among Wheat Dominated Rural Households in Sinana District, Bale Zone, Ethiopia." Agriculture \& Food Security 10(1): 1-15. 
Milazzo, A., and D. Van de Walle. 2015. "Women Left Behind? Poverty and Headship in Africa." Policy Research Working Paper. Washington, D.C.: The World Bank.

Muraoka, R., S. Jin, and T.S. Jayne. 2018. "Land Access, Land Rental and Food Security: Evidence From Kenya." Land Use Policy 70: 611-622.

Murugani, V.G., J.M. Thamaga-Chitja, U. Kolanisi, and H. Shimelis. 2014. "The Role of Property Rights on Rural Women's Land Use Security and Household Food Security for Improved Livelihood in Limpopo Province." Journal of Human Ecology 46(2): 205-221.

NBS. 2016. General Household Survey-Panel Wave 3 (Post Harvest) 2015-2016. Edited by National Bureau of Statistics (NBS), Federal Government of Nigeria (FGN).

Norton, E.C., H. Wang, and C. Ai. 2004. "Computing Interaction Effects and Standard Errors in Logit and Probit Models.” Stata Journal 4: 154-167.

Oginni, A., B. Ahonsi, and F. Ukwuije. 2013. "Are Female-Headed Households Typically Poorer Than Male-Headed Households in Nigeria?” The Journal of Socio-Economics 45: 132-137.

Pinckney, T.C., and P.K. Kimuyu. 1994. "Land Tenure Reform in East Africa: Good, Bad or Unimportant?" Journal of African Economies 3(1): 1-28.

Pindiriri, C. 2021. Land Inequality, Gender Land Disparity and Poverty in Rural Zimbabwe. Nairobi: African Economic Research Consortium

Quisumbing, A.R., L. Haddad, R. Meinzen-Dick, and L.R. Brown. 1998. "Gender Issues for Food Security in Developing Countries: Implications for Project Design and Implementation." Canadian Journal of Development Studies/Revue canadienne d'études du développement 19(4): 185-208.

Rammohan, A., and B. Pritchard. 2014. "The Role of Landholding as a Determinant of Food and Nutrition Insecurity in Rural Myanmar.” World Development 64: 597-608.

Rao, N. 2006. "Land Rights, Gender Equality and Household Food Security: Exploring the Conceptual Links in the Case of India." Food Policy 31(2): 180-193.

Rogers, B.L. 1996. "The Implications of Female Household Headship for Food Consumption and Nutritional Status in the Dominican Republic." World Development 24(1): 113-128.

Ruwanpura, K., and J. Humphries. 2003. Female-Headship in Eastern Sri Lanka: A Comparative Study of Ethnic Communities in the Context of Conflict. Geneva: International Labour Office Recovery and Reconstruction Department, Geneva, Recovery and Reconstruction Department, International Labour Office (Geneva, Switzerland: International Labour Organization).

Sasson, A. 2012. "Food Security for Africa: An Urgent Global Challenge." Agriculture \& Food Security 1(1): 2.

Shin, Y. 2020. How the Gender of the Household's Head Influences Household Food Security in the Developing Countries. Seoul: Seoul National University.

Tefera, T., and F. Tefera. 2014. "Determinants of Households Food Security and Coping Strategies for Food Shortfall in Mareko District, Guraghe Zone Southern Ethiopia." Journal of Food Security 2(3): 92-99.

Tekwa, N. 2020. Gender, Land Reform and Welfare Outcomes: A Case Study of Chiredzi District, Zimbabwe. Pretoria: Sociology, University of South Africa.

Tibesigwa, B., and M. Visser. 2016. "Assessing Gender Inequality in Food Security Among Small-Holder Farm Households in Urban and Rural South Africa." World Development 88: 33-49.

Tran, T.N., H. Cam, N.T.P. Le Thanh Sang, N.T.P.L. Cham, and V.T. Long. 2013. Women's Access to Land in Contemporary Việt Nam. Hanoi: United Nations Development Programme.

Twum, K.O., K. Asiama, J. Ayer, and C.Y. Asante. 2020. "Gender, Land and Food Access in Ghana's Suburban Cities: A Case of the Adenta Municipality." Land 9(11): 427.

Valente, C. 2009. "The Food (In) Security Impact of Land Redistribution in South Africa: Microeconometric Evidence from National Data." World Development 37(9): 1540-1553.

Wineman, A., and L.S.O. Liverpool-Tasie. 2017. "Land Markets and Land Access Among Female-Headed Households in Northwestern Tanzania." World Development 100: 108-122.

Xie, H., Y. Wen, Y. Choi, and X. Zhang. 2021. "Global Trends on Food Security Research: A Bibliometric Analysis." Land 10(2): 119. 


\section{Appendix}

Table A1. Estimation Results of the Food Insecurity Model with and without the Gender-Land Interaction Term

\begin{tabular}{|c|c|c|}
\hline Explanatory variables & With IT & Without IT \\
\hline Farm size & $0.938(0.028)^{\star \star}$ & $0.935(0.029)^{\star \star}$ \\
\hline Gender & $2.008(0.659)^{\star \star}$ & $1.336(0.354)$ \\
\hline Gender ${ }^{\star}$ land & $0.299(0.197)^{*}$ & \\
\hline Age & $1.001(0.006)$ & $1.000(0.006)$ \\
\hline Age squared & $1.000(0.000)$ & $1.000(0.000)$ \\
\hline Household size & $0.975(0.024)$ & $0.974(0.024)$ \\
\hline Location & $1.076(0.209)$ & $1.079(0.209)$ \\
\hline Electricity & $1.054(0.161)$ & $1.064(0.162)$ \\
\hline Education & $0.833(0.066)^{\star \star}$ & $0.832(0.066)^{\star \star}$ \\
\hline Nonfarm income & $1.000(0.000)$ & $1.000(0.000)$ \\
\hline Farm income & $1.000(0.000)^{\star \star \star}$ & $0.999(0.000)^{\star \star \star}$ \\
\hline Remittance & $1.900(0.779)$ & $1.925(0.784)$ \\
\hline Extension officer visits & $0.960(0.078)$ & $0.958(0.075)$ \\
\hline Land title & $0.948(0.289)$ & $0.958(0.292)$ \\
\hline Fertilizer use & $0.682(0.076)^{\star \star \star}$ & $0.686(0.076)^{\star \star \star}$ \\
\hline Soil quality & $0.611(0.108)^{\star \star \star}$ & $0.620(0.109)^{\star \star *}$ \\
\hline Distance to market & $0.997(0.002)$ & $0.997(0.002)$ \\
\hline Constant & $1.167(0.636)$ & $1.147(0.623)$ \\
\hline Sample & 1,096 & 1,096 \\
\hline$p>\chi^{2}$ & 0.000 & 0.000 \\
\hline $\mathrm{R}^{2}$ & 0.0701 & 0.0662 \\
\hline Log-likelihood & -634.096 & -636.752 \\
\hline
\end{tabular}

Notes: ${ }^{\star * \star}$, and ${ }^{* \star \star}$ represent significance at 10,5 , and 1 percent levels, respectively; the SE values are in parenthesis; and IT denotes the interaction term. Dependent variable equals 1 if household is classified as food insecure and 0 otherwise.

Cite this article: Nnaji A, Ratna NN, Renwick A (2022). Gendered access to land and household food insecurity: Evidence from Nigeria. Agricultural and Resource Economics Review 51, 45-67. https://doi.org/10. 1017/age.2021.13 